\title{
Influence of Aging Procedure on Bonding Strength and Thermal Conductivity of Plywood Panels
}

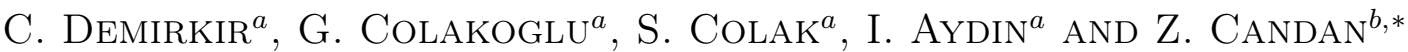 \\ ${ }^{a}$ Department of Forest Products Engineering, Faculty of Forestry, Karadeniz Technical University, Trabzon, Turkey \\ ${ }^{b}$ Department of Forest Products Engineering, Faculty of Forestry, Istanbul University, Sariyer, Istanbul, Turkey
}

(Received August 26, 2015; in final form May 6, 2016)

\begin{abstract}
Wood and wood composite materials have been used in house, school, and office construction throughout the world. Wood composite materials are superior to other building materials in terms of thermal conductivity due to its porous structure. Bonding strength and thermal conductivity are two of many other significant properties of composite panels used in construction. It was essential to determine the effect of ageing process on the properties of panels used in structural applications. This study evaluates thermal conductivity and bonding strength of Scots pine and black pine plywood panels manufactured from rotary cut veneers dried at three different temperatures: $110^{\circ} \mathrm{C}$, $140^{\circ} \mathrm{C}$, and $160^{\circ} \mathrm{C}$. Phenol formaldehyde (PF) and melamine urea formaldehyde (MUF) were used as adhesives for plywood manufacturing. Panels were exposed to ageing process according to ASTM C 481-99 standard. Plywood panels with five plies and $10 \mathrm{~mm}$ thickness were manufactured for each group. Thermal conductivity and bonding strength values of plywood panels were determined. Thermal conductivity of the panels decreased with increase of the drying temperature. It was also found that the thermal conductivity of test panels decreased after the ageing process. Shear strength mean values obtained from the samples of all plywood panels were above the limit value $\left(1.0 \mathrm{~N} / \mathrm{mm}^{2}\right)$ indicated in TS EN 314-2 standard but those of the panels with MUF after ageing process.
\end{abstract}

DOI: 10.12693/APhysPolA.129.1230

PACS/topics: 88.20.rp, 87.85.jf

\section{Introduction}

Wood and wooden structure materials have been used in house, school and office construction in many countries. Wood framed buildings are composed of framing studs or joists, sheathing materials (plywood, oriented strand board (OSB)), and fasteners (nails, screws) [1]. The most common materials used as sheathing are plywood and OSB [2]. In Turkey, production capacity of plywood panels as wood composite was $180,000 \mathrm{~m}^{3}$ and $247,000 \mathrm{~m}^{3}$ in 2010 and 2013, respectively [3]. Wood composite material is superior to other building materials in terms of thermal conductivity due to its porous structure $[4,5]$. Plywood panels have well-balanced thermal insulation and warmth keeping properties (steady and non-steady-states), which is important for insulation performance in that they maintained temperature and relax severe temperature changes in residences exposed to diurnal and seasonal temperature changes $[6,7]$.

In plywood production, veneer drying is a different thermal process affecting veneer quality for bonding, durability and physical and mechanical properties of panels. The purpose of veneer drying is to reduce its moisture content to a suitable range for gluing. Mostly applied drying temperatures are between 90 and $160^{\circ} \mathrm{C}$ as called normal in plywood industry. Using high drying temperatures reduces the veneer drying time and increases the capacity. Reduction in drying time and energy consumption offers a great potential for economic benefit to the

*corresponding author; e-mail: zekic@istanbul.edu.tr wood industries [8]. However, drying at very low moisture levels and at very high temperatures or at moderate temperatures for prolonged periods inactivates the veneer surfaces, causing poor wetting of veneer and hence poor bonding [9]. Drying temperature influences both physical and chemical surface properties of veneer and hence its thermal conductivity characteristics. Numerous studies have been carried out for the effects of veneer drying temperatures on bondability of veneer surfaces $[10,11]$, surface-inactivation and bond strength relationship [9] and optimum conditions for surface preparation [12]. However, the number of studies about the thermal conductivity of plywood panels related to the different drying temperatures were at not adequate level.

Sustaining to durability of wood-based panels is one of the most important features for structural products used in construction of houses [13]. It is known that wood is deteriorated when it is exposed to outdoor conditions. Xie et al. [14] stated that weathering of wood is caused by various factors such as solar radiation, heat, atmospheric pollutants and micro-organisms. Several studies have been researched about sustaining durability of wood and wood composite materials $[15,16]$. The durability or moisture resistance of structural panels (plywood, OSB) is usually determined by standardized ageing test methods that include various cycles of cold or hot water immersion, boiling, steaming, freezing, and drying [13]. Variation of moisture content in wood can cause cracks and loss of mechanical and physical properties of wood. It has been thought that thermal conductivity could be affected by variation of moisture content in wood and wood based materials by weathering. It was stated that thermal conductivity of wood 
and wood composite materials such as plywood, OSB, medium density fiberboard (MDF), particleboard has varied according to wood specie, direction of wood fiber, ratio of early and late wood, thickness of composite materials, density, moisture content, resin type and additives, temperature, and flow direction of heat in several studies $[17-19]$. But there are few studies of the effect of ageing factors in using place on thermal conductivity of wood composite materials.

In this study, there was studied the effect of ageing process and some manufacturing factors such as wood species, drying temperatures of veneer, adhesive types on the thermal conductivity of structural plywood panels. But there were also evaluated the bonding strength values of test panels to determine the effect of ageing process on mechanical properties of them.

\section{Material and method}

\subsection{Wood material}

Scots pine (Pinus sylvestris) and black pine (Pinus nigra) were used as wood species in this study. Densities of Scots pine and black pine (Pinus nigra) were $0.48 \mathrm{~g} / \mathrm{cm}^{3}$ and $0.56 \mathrm{~g} / \mathrm{cm}^{3}$, respectively. Logs for veneer manufacturing with an average diameter at breast height of $40 \mathrm{~cm}$ were obtained from Sinop, located at the most northern point of the Black Sea region of Turkey. A rotary peeler with a maximum horizontal holding capacity of $80 \mathrm{~cm}$ was used for veneer manufacturing. The logs were steamed before the peeling process, and then veneer sheets with dimensions of $55 \mathrm{~cm} \times 55 \mathrm{~cm} \times 2 \mathrm{~mm}$ were clipped. The vertical opening was $0.5 \mathrm{~mm}$ and horizontal opening was $85 \%$ of the veneer thickness in the veneer manufacturing process. After rotary peeling, veneers were dried until moisture content of them reaches to $4-6 \%$ at three different temperatures: $110^{\circ} \mathrm{C}, 140^{\circ} \mathrm{C}$, and $160^{\circ} \mathrm{C}$ in a veneer dryer.

\subsection{Composite manufacturing}

Five-ply-plywood panels with $10 \mathrm{~mm}$ thickness were manufactured using PF resin with $47 \%$ solid content and MUF resin with $55 \%$ solid content (melamine-to-urea ratio of $60: 40)$. MUF resin solution used in the manufacturing was composed of 100 parts of MUF resin by weight, 30 parts of wheat flour by weight, and 10 parts of $15 \%$ concentrated $\mathrm{NH}_{4} \mathrm{Cl}$ by weight. The $\mathrm{PF}$ resin

TABLE I

Experimental panel groups.

\begin{tabular}{c|c|c|c}
\hline \hline Glue & Veneer drying & \multicolumn{2}{|c}{ Wood species } \\
\cline { 3 - 4 } Type & temperature $\left[{ }^{\circ} \mathrm{C}\right]$ & Scots pine & Black pine \\
\hline \multirow{3}{*}{ PF } & 110 & A1 & C1 \\
& 140 & A2 & C2 \\
& 160 & A3 & C3 \\
\hline \multirow{3}{*}{ MUF } & 110 & A4 & C4 \\
& 140 & A5 & C5 \\
& 160 & A6 & C6
\end{tabular}

used in this study was supplied by Polisan Chemical Company, Kocaeli, Turkey. The PF resin was used for plywood panel manufacturing without any filler or additive. Veneer sheets were conditioned to approximately 5-7\% moisture content in a conditioning chamber before gluing. The glue was applied at a rate of $160 \mathrm{~g} / \mathrm{m}^{2}$ to the single surface of veneer using a four-roller spreader. The assembled veneers were pressed in a hot press at a pressure of $8 \mathrm{~kg} / \mathrm{cm}^{2}$. Two replicate plywood panels were manufactured from each group. The experimental panel groups are shown in Table I.

\subsection{Bonding strength test procedure}

The bonding strength of plywood panels was determined according to TS 3969 EN 314-1 [20] standard by a universal testing machine. Samples manufactured with $\mathrm{PF}$ resin were immersed in boiling water for $6 \mathrm{~h}$ and the samples with MUF were immersed in water at $20^{\circ} \mathrm{C}$ for $24 \mathrm{~h}$ prior to testing in wet state. Twenty five specimens were used for the evaluation of bonding strength tests. Each sample was cut as shown in Fig. 1 for bonding strength test according to TS 3969 EN 314-1.
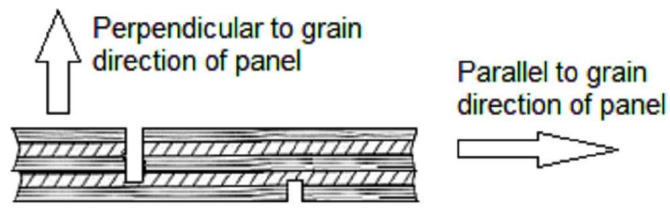

Fig. 1. Bonding strength test sample.

\subsection{Thermal conductivity test procedure}

A quick thermal conductivity meter based on ASTM C 1113-99 [21] hot-wire method was used. QTM 500 device, a product of Kyoto Electronics Manufacturing, Japan, was used for thermal conductivity measurement with PD11 probe.

Measurement range is $0.0116-6 \mathrm{~W} / \mathrm{mK}$. Measurement precision is $\mathrm{F} 5 \%$ of reading value per reference plate. Reproducibility is $\mathrm{F} 3 \%$ of reading value per reference plate. Measurement temperature is -100 to $1000{ }^{\circ} \mathrm{C}$ (external bath or electric furnace for temperature other than room). Sizes of the test specimens are $10 \times 50 \times 100 \mathrm{~mm}^{3}$. Measuring time is standard $100-120$ s. Five specimens were used for each group.

\subsection{Ageing procedure}

Standard test method for laboratory ageing of sandwich constructions covers the determination of the resistance of composite panels to severe exposure conditions as measured by the change in selected properties of the material after exposure. The exposure cycle to which the specimens were subjected was an arbitrary test having no correlation with natural weathering conditions [22].

Laboratory ageing test method was conducted according to ASTM C 481-99 [22] standard. Ageing process was given below:

- Totally immerse the specimen horizontally in water at $50 \pm 3^{\circ} \mathrm{C}$ for $1 \mathrm{~h}$.

- Heat in dry air at $70 \pm 3^{\circ} \mathrm{C}$ for $3 \mathrm{~h}$. 
- Spray with hot water at $70 \pm 3{ }^{\circ} \mathrm{C}$ for $3 \mathrm{~h}$.

- Heat in dry air at $70 \pm 3^{\circ} \mathrm{C}$ for $18 \mathrm{~h}$.

After completion of the cycles of exposure, the specimens were conditioned at a temperature of $23 \pm 3{ }^{\circ} \mathrm{C}$ and a relative humidity of $50 \pm 5 \%$ to constant weight $( \pm 1 \%)$ before testing. The equation below was used to calculate the degradation percentages:
Degradation percentage $=\frac{\text { Conditioned test value }}{\text { Nonaged test value }} \times 100 \%$.

\section{Results and discussion}

3.1. Bonding strength

The mean values of bonding strength and thermal conductivity of plywood panels are listed in Table II.

TABLE II

Bonding strength and thermal conductivity of the plywood panels.

\begin{tabular}{|c|c|c|c|c|c|c|c|}
\hline \multirow{2}{*}{$\begin{array}{l}\text { Wood } \\
\text { species }\end{array}$} & \multirow{2}{*}{$\begin{array}{l}\text { Glue } \\
\text { types }\end{array}$} & \multirow{2}{*}{$\begin{array}{c}\text { Veneer } \\
\text { drying } \\
\text { temperatures } \\
{\left[{ }^{\circ} \mathrm{C}\right]}\end{array}$} & \multirow{2}{*}{$\begin{array}{l}\text { Density } \\
{\left[\mathrm{g} / \mathrm{cm}^{3}\right]}\end{array}$} & \multicolumn{2}{|c|}{$\begin{array}{l}\text { Bonding strength } \\
\qquad\left[\mathrm{N} / \mathrm{mm}^{2}\right]\end{array}$} & \multicolumn{2}{|c|}{$\begin{array}{l}\text { Thermal conductivity } \\
{[\mathrm{W} / \mathrm{mK}]}\end{array}$} \\
\hline & & & & $\begin{array}{l}\text { Before } \\
\text { ageing }\end{array}$ & $\begin{array}{c}\text { After } \\
\text { ageing }\end{array}$ & $\begin{array}{l}\text { Before } \\
\text { ageing }\end{array}$ & $\begin{array}{c}\text { After } \\
\text { ageing }\end{array}$ \\
\hline \multirow{6}{*}{$\begin{array}{l}\text { Scots } \\
\text { pine }\end{array}$} & \multirow{3}{*}{$\mathrm{PF}$} & 110 & $0.58(0.02)$ & $1.44(0.19)^{*}$ & $1.44(0.16)$ & $0.11(0.008)$ & $0.10(0.006)$ \\
\hline & & 140 & $0.58(0.03)$ & $1.63(0.12)$ & $1.61(0.16)$ & $0.11(0.004)$ & $0.09(0.001)$ \\
\hline & & 160 & $0.54(0.04)$ & $1.57(0.11)$ & $1.53(0.09)$ & $0.10(0.004)$ & $0.10(0.001)$ \\
\hline & \multirow{3}{*}{ MUF } & 110 & $0.58(0.02)$ & $1.30(0.08)$ & $0.88(0.17)$ & $0.11(0.002)$ & $0.09(0.008)$ \\
\hline & & 140 & $0.55(0.02)$ & $1.24(0.09)$ & $0.82(0.12)$ & $0.10(0.003)$ & $0.09(0.002)$ \\
\hline & & 160 & $0.54(0.02)$ & $1.18(0.16)$ & $0.77(0.11)$ & $0.10(0.001)$ & $0.09(0.005)$ \\
\hline \multirow{6}{*}{$\begin{array}{l}\text { Black } \\
\text { pine }\end{array}$} & \multirow{3}{*}{$\mathrm{PF}$} & 110 & $0.59(0.02)$ & $1.65(0.11)$ & $1.65(0.15)$ & $0.10(0.001)$ & $0.10(0.010)$ \\
\hline & & 140 & $0.59(0.02)$ & $1.76(0.12)$ & $1.75(0.14)$ & $0.11(0.001)$ & $0.10(0.003)$ \\
\hline & & 160 & $0.59(0.02)$ & $1.68(0.17)$ & $1.68(0.18)$ & $0.10(0.001)$ & $011(0.003)$ \\
\hline & \multirow{3}{*}{ MUF } & 110 & $0.63(0.02)$ & $1.73(0.14)$ & $0.91(0.17)$ & $0.11(0.001)$ & $0.10(0.003)$ \\
\hline & & 140 & $0.60(0.03)$ & $1.61(0.15)$ & $0.88(0.19)$ & $0.11(0.005)$ & $0.11(0.003)$ \\
\hline & & 160 & $0.62(0.02)$ & $1.42(0.13)$ & $0.89(0.22)$ & $0.11(0.007)$ & $0.11(0.002)$ \\
\hline
\end{tabular}

*Values in parenthesis are standard deviations.

As can be seen in Table II, plywood panels manufactured from black pine gave higher bonding strength values than those of the Scots pine panels. This may be explained by the fact of the positive correlation among the raw wood density, plywood density and plywood bonding strength. It was found that the density values of panels from black pine were higher than those of Scots pine plywood panels. Similar results were determined in the previous studies [23, 24]. The Student-Newman-Keuls test with $99 \%$ confidence level was used to compare the mean values of variance sources and the results for statistical evaluation were presented in Table III.

It is seen in Table III that the effect of ageing process, wood species, glue type and drying temperature on bonding strength is statistically significant. Bonding shear strength mean values obtained from the samples of all plywood panels were also above the limit value $\left(1.0 \mathrm{~N} / \mathrm{mm}^{2}\right)$ indicated in TS EN 314-2 [25] standard. The limit value in the standard indicates the minimum standard requirement for bonding strength. Therefore the plywood panels tested in this study have met the standard requirement for the bonding strength.

It was determined that the bonding strength values of the plywood panels made with PF were higher than those of the panels with MUF. It is known that glue properties such as glue type, ingredients, and gel time have an important effect on the bonding strength [24, 26, 27]. According to Colak et al. [28] and Tan [29], laminated veneer lumber (LVL) and plywood panels made with $\mathrm{PF}$ gave the better bonding strength values when they were compared to the panels with MUF. As can be seen in Table II, bonding strength values of plywood panels manufactured with PF resin were not influenced from ageing process, while those of panels manufactured with MUF resin decreased after ageing process. The degradation ratios of bonding strength values of panels with MUF resin ranged from $32 \%$ to $47 \%$ after the ageing process. It was concluded from the study that $\mathrm{PF}$ resin was more favorable than MUF resin for outdoor applications. These findings were confirmed in former studies showing that phenolic-based adhesives should be used for structural plywood panels for exterior use [30-32]. Products made with PF, resorcinol formaldehyde, and phenolresorcinol-formaldehyde adhesives have also proven to be more durable than wood when exposed to warm and humid environments, water, alternate wetting and drying, and even temperatures sufficiently high to char wood by Pizzi [33] and Vick [34]. But products well-made 
TABLE III

Results of Student-Newman-Keuls test at $99 \%$ confidence level.

\begin{tabular}{|c|c|c|c|c|}
\hline Properties & \multicolumn{2}{|c|}{ Factors } & $\begin{array}{c}\text { Least } \\
\text { squares }\end{array}$ & $\begin{array}{l}\text { Homo- } \\
\text { geneous }\end{array}$ \\
\hline \multirow{9}{*}{$\begin{array}{l}\text { bonding } \\
\text { strength }\end{array}$} & \multirow{2}{*}{$\begin{array}{l}\text { ageing } \\
\text { process }\end{array}$} & before & 1.52 & $\mathrm{a}$ \\
\hline & & after & 1.24 & $\mathrm{~b}$ \\
\hline & \multirow{2}{*}{$\begin{array}{c}\text { wood } \\
\text { species }\end{array}$} & Scots pine & 1.28 & $\mathrm{a}$ \\
\hline & & black pine & 1.47 & $\mathrm{~b}$ \\
\hline & \multirow{2}{*}{$\begin{array}{l}\text { glue } \\
\text { type }\end{array}$} & $\mathrm{PF}$ & 1.62 & $\mathrm{a}$ \\
\hline & & MUF & 1.14 & $\mathrm{~b}$ \\
\hline & \multirow{3}{*}{$\begin{array}{c}\text { drying } \\
\text { temperature }\end{array}$} & $110^{\circ} \mathrm{C}$ & 1.38 & $\mathrm{a}$ \\
\hline & & $140^{\circ} \mathrm{C}$ & 1.41 & $\mathrm{ab}$ \\
\hline & & $160^{\circ} \mathrm{C}$ & 1.34 & $\mathrm{c}$ \\
\hline \multirow{9}{*}{$\begin{array}{c}\text { thermal } \\
\text { conductivity }\end{array}$} & \multirow{2}{*}{$\begin{array}{l}\text { ageing } \\
\text { process }\end{array}$} & before & 0.108 & $\mathrm{a}$ \\
\hline & & after & 0.102 & $\mathrm{~b}$ \\
\hline & \multirow{2}{*}{$\begin{array}{c}\text { wood } \\
\text { species }\end{array}$} & Scots pine & 0.102 & $\mathrm{a}$ \\
\hline & & black pine & 0.108 & $\mathrm{~b}$ \\
\hline & \multirow{2}{*}{$\begin{array}{l}\text { glue } \\
\text { type }\end{array}$} & $\mathrm{PF}$ & 0.106 & $\mathrm{a}$ \\
\hline & & MUF & 0.104 & $\mathrm{~b}$ \\
\hline & \multirow{3}{*}{$\begin{array}{c}\text { drying } \\
\text { temperature }\end{array}$} & $110^{\circ} \mathrm{C}$ & 0.108 & $\mathrm{a}$ \\
\hline & & $140^{\circ} \mathrm{C}$ & 0.104 & $\mathrm{~b}$ \\
\hline & & $160^{\circ} \mathrm{C}$ & 0.103 & $\mathrm{bc}$ \\
\hline \multirow{7}{*}{ density } & \multirow{2}{*}{$\begin{array}{l}\text { wood } \\
\text { species }\end{array}$} & Scots pine & 0.56 & $\mathrm{a}$ \\
\hline & & black pine & 0.61 & $\mathrm{~b}$ \\
\hline & \multirow{2}{*}{$\begin{array}{l}\text { glue } \\
\text { type }\end{array}$} & $\mathrm{PF}$ & 0.58 & $\mathrm{a}$ \\
\hline & & MUF & 0.59 & $\mathrm{~b}$ \\
\hline & \multirow{3}{*}{$\begin{array}{c}\text { drying } \\
\text { temperature }\end{array}$} & $110^{\circ} \mathrm{C}$ & 0.60 & $\mathrm{a}$ \\
\hline & & $140^{\circ} \mathrm{C}$ & 0.58 & $\mathrm{~b}$ \\
\hline & & $160^{\circ} \mathrm{C}$ & 0.57 & $\mathrm{bc}$ \\
\hline
\end{tabular}

${ }^{a}$ Different letters denote a statistically significant difference.

with melamine-formaldehyde (MF), MUF, and ureaformaldehyde (UF) resin adhesives are less durable than wood [33, 34].

As shown in Table III, there is a significant effect of veneer drying temperature on the bonding strength. The bonding strength values of plywood panels with PF resin increased, as the veneer drying temperature increased until $140^{\circ} \mathrm{C}$. Aydin [35] was found that bonding strength values of plywood panels manufactured from veneers dried at $150^{\circ} \mathrm{C}$ was higher than those of the panels manufactured from veneers dried at $110^{\circ} \mathrm{C}$. As can be seen from Table II, when raising the drying temperature from $140^{\circ} \mathrm{C}$ to $160^{\circ} \mathrm{C}$, bonding strength values of panels with PF resin have decreased. It is also seen the bonding strength values of test panels with MUF resin have decreased, as the drying temperature of the rotary veneers has been raised. This may be explained with surface inactivation that is one of the defects which occur on wood surfaces with heat effect occurring in wood surface. A wood surface, which is exposed to high temperature condition, can experience surface inactivation hence some physical and chemical changes occurred on the wood surfaces that results in reduced ability of the adhesive to properly wet, flow, penetrate and cure [35]. This results in loss of bonding ability. There was no significant difference between bonding strength values of panels made from veneers dried at $110^{\circ} \mathrm{C}$ and those of panels from veneers dried at $140^{\circ} \mathrm{C}$. Both of them were in the same homogeneous groups as seen from Table III.

\subsection{Thermal conductivity}

Thermal conductivity of the plywood panels from black pine was higher than those of the panels from Scots pine as seen from Table II. It could be explained that plywood panels from black pine had higher density than panels from Scots pine as shown in Table II. It was reported that thermal conductivity mainly varied according to wood species due to their different density values [36-38]. Because, as wood having higher density, it is true that it has less space to store air causing to increase in thermal conductivity [39]. Urukami and Kukuyama [40] also found that thermal conductivity increased with increasing wood density.

In this study, in general, thermal conductivity of Scots pine panels decreased with increasing the veneer drying temperature, except for plywood manufactured with $\mathrm{PF}$ resin and veneers dried at $140{ }^{\circ} \mathrm{C}$ and $160^{\circ} \mathrm{C}$ when thermal conductivity actually increased. The results of Student-Newman-Keuls also proved that there was no significant difference between thermal conductivity of panels from veneers dried at $140^{\circ} \mathrm{C}$ and $160^{\circ} \mathrm{C}$ with respect to drying temperature with 0.001 error probabilities as shown in Table III. This situation can be explained with decrease in density of the plywood panels with increase of the veneer drying temperature. Based on the density values, the similar results can be observed in Table III with respect to drying temperature.

According to the Newman-Keuls results with 0.001 error probabilities in Table III, in general, thermal conductivity values of test panels decreased with ageing process. Considering the ageing process steps, moisture content of the panels might have not reached the values they had before ageing process because of hysteresis even if they were exposed to the conditions defined the concerning standard [41]. Therefore, decrease in the thermal conductivity after ageing process may be due to decrease of the moisture content of the panels.

\section{Conclusions}

Two of the most important properties of composite panels used in construction are bonding strength and thermal conductivity. It is essential to determine the effect of ageing process on the properties of panels used in structural applications. In this study, the effect of some manufacturing factors and ageing process on bonding strength and thermal conductivity of plywood panels was determined.

There was no significant effect of ageing process on the bonding strength values of plywood panels with PF resin, while those of panels with MUF resin decreased after ageing process. It was concluded that $\mathrm{PF}$ resin should 
be used in place of MUF resin in manufacturing of composite plywood panels for outdoor applications. It can be suggested that these panels can be used as sheathing material in shear walls of wood frame buildings. Bonding strength mean values obtained from all test panels were above the minimum value $\left(1.0 \mathrm{~N} / \mathrm{mm}^{2}\right)$ indicated in TS EN 314-2 standard but those of the panels with MUF after ageing process. It was concluded from the study that the effects of veneer drying temperatures and ageing process on the thermal conductivity of test panels were significant.

\section{Acknowledgments}

The authors acknowledge the financial support of the Scientific and Technological Research Council of Turkey (TUBITAK). This manuscript is an extension and continuation of the study presented at the SWST 2015, WY, USA.

\section{References}

[1] C.C. Yan, Ph.D. Thesis, Washington State University, Washington 1992.

[2] D.E. Breyer, K.J. Fridley, D.G. Pollock, K.E. Cobeen, Design of Wood Structures - ASD, 5th ed., McGrawHill, New York 2003.

[3] Z. Candan, T. Akbulut, Composites Part B Eng. 64, 155 (2014).

[4] H.M. Gu, A. Zink-Sharp, Wood Fiber Sci. 37, 699 (2005).

[5] E.L. Kruger, M. Adriazola, Construct. Build. Mater. 24, 999 (2010).

[6] T. Kawasaki, S. Kawai, J. Wood Sci. 52, 75 (2006).

[7] T. Akgul, A.C. Apay, E. Aydin, Y. Sumer, Acta Phys. Pol. A 127, 1414 (2015).

[8] I. Aydin, G. Colakoglu, Dry. Technol. 23, 1107 (2005).

[9] R.C. Frihart, C.G. Hunt, Adhesive with wood materials, bond formation and performance, wood handbook wood as an engineering material, Centennial Edition, General Technical Report FPL-GTR-190. U.S. United States Department of Agriculture, Forest Prod. Lab., Madison, WI 2010, Ch. 10.

[10] A.W. Christiansen, Wood Fiber Sci. 22, 441 (1990).

[11] M. Lehtinen, Effects of manufacturing temperatures on the properties of plywood, Helsinki University of Technology, Laboratory of Structural Engineering and Building Physics, TRT Report No. 92, Finland 1988.

[12] B.H. River, C.B. Vick, R.H. Gillespie, in: Treatise on Adhesion and Adhesives, Ed. J.D. Minford, Marcel Dekker, New York 1991.

[13] H. Norita, Y. Kojima, S. Suzuki, J. Wood Sci. 54, 121 (2008).

[14] Y. Xie, A. Krause, C. Mai, H. Militz, K. Richter, K. Urban, R.D. Evans, Polym. Degrad. Stabil. 89, 189 (2005).

[15] P.O.A. Karlsson, J.D. McNatt, S.P. Verrill, Forest Prod. J. 46, 84 (1996).

[16] C.H.S. Menezzi, R.Q. Souza, R.M. Thompson, D.E. Teixeira, Y.A. Okino, A.F. Da Costa, Int. Biodeter. Biodeg. 62, 448 (2008).
[17] H. Bader, P. Niemz, W. Sonderegger, Holz. Roh. Werkst. 65, 173 (2007).

[18] W. Sonderegger, P. Niemz, Eur. J. Wood Wood Prod. 67, 313 (2009).

[19] H.S. Kol, A. Ozcifci, S. Altun, Kastamonu Univ. J. Forestry Faculty 8, 125 (2008).

[20] TS 3969 EN 314-1, Plywood-bonding quality-part 1: test methods, Turkish Standard Institute (TSE), Ankara, Turkey 1998.

[21] ASTM C 1113/M 1113-09, Standard test method for thermal conductivity of refractories by hot wire (platinum resistance thermometer technique), USA 2009.

[22] ASTM C 481-99, Standard test method for laboratory ageing of sandwich constructions, USA 2005.

[23] I. Aydin, Ph.D. Thesis, Karadeniz Technical University, Trabzon, Turkey 2004.

[24] G. He, C. Yu, C. Dai, Wood Fiber Sci. 39, 566 (2007).

[25] TS EN 314-2, Plywood-bonding quality-part 2: requirements, Turkish Standard Institute (TSE), Ankara, Turkey 1999.

[26] J.A. Youngquist, G.C. Myers, L.L. Murmanis, Wood Fiber Sci. 19, 215 (1987).

[27] F.A. Kamke, E. Kultikova, C.A. Lenth, in: The Fourth Int. Panel and Engineered-Wood Technology Conf. \& Exposition, Atlanta (USA), Atlanta 1996, p. 147.

[28] S. Colak, I. Aydın, C. Demirkir, G. Colakoglu, Turkish J. Agricul. Forestry 28, 109 (2004).

[29] H. Tan, Ph.D. Thesis, Karadeniz Technical University, Trabzon, Turkey 2011.

[30] Structural Plywood \&5 LVL Design Manual, EWPAA (Engineered Wood Products Association of Australasia), Australia 2010.

[31] PS 2-10 Performance standard for wood-based structural-use panels, APA (The Engineered Wood Association), Form No. S350F/Revised June 2011/0400, 2011.

[32] Structural adhesives for plywood-lumber assemblies, APA (The Engineered Wood Association), Technical Note, Number Y391 C WA, USA 1998.

[33] A. Pizzi, Wood Adhesives; Chemistry and Technology, Vol. 1, Marcel Dekker, New York 1983.

[34] C.B. Vick, Adhesive bonding of wood materials, wood handbook - wood as an engineered material, Ch. 9, FPL-GTR-113, Department of Agriculture, Forest Service, Forest Product Laboratory, Madison, WI 1999

[35] I. Aydın, Artvin Coruh Univ. J. Forestry Faculty 1-2, 1 (2004).

[36] W.A. Baker,in: APA Engineered Wood Handbook, Ed. T.G. Williamson, USA 2002, Ch. 2, p. 2.1.

[37] R.W. Rice, R. Shepard, Forest Prod. J. 54, 92 (2004).

[38] H.S. Kol, Y. Sefil, J. Appl. Polym. Sci. 121, 2473 (2011).

[39] B.M. Suleiman, J. Larfeldt, B. Leckner, M. Gustavsson, Wood Sci. Technol. 33, 465 (1999).

[40] H. Urukami, M. Kukuyama, Wood Sci. Technol. 33, 465 (1981).

[41] Y. Ors, H. Keskin, Knowledge of Wood Materials, Atlas Publ., Turkey 2001. 